\title{
Antecedents of Customers Loyalty towards Go-Jek Service
}

\author{
Helmy Ilham Nugraha ${ }^{1}$, Anas Hidayat $^{2}$, Putra Endi Catyanadika $^{3}$, Sri Rejeki Ekasasi ${ }^{4 凶}$ \\ Universitas Islam Indonesia ${ }^{1,2,3}$ \\ Sekolah Tinggi Ilmu Manajemen YKPN ${ }^{4}$ \\ e-mail: srirejekiekasasi@gmail.com
}

\begin{abstract}
Service quality is one of the biggest factors in determining consumer loyalty. The aim of this study is to analyze how the Go-Jek service quality an influence customer satisfaction in shaping customer loyalty to the Go-Jek company. This research is quantitative and the variables examined in this study are website design, reliability, trust, customer satisfaction, to support consumer loyalty. This research was conducted in Yogyakarta and the data was collected using a questionnaire based on a Likert-scale, and the taking method uses purposive sampling with 300 respondents. Data were then analyzed using structural equation model (SEM) analysis with the help of WarpPLS software. The results of the study show that the effect of e-service quality on customer loyalty to the Go-Jek company were positive and significant.
\end{abstract}

Keywords: e-service quality, website design, reliability, customer satisfaction, customer loyalty

\begin{abstract}
Abstrak
Kualitas pelayanan merupakan salah satu faktor terbesar dalam menentukan loyalitas konsumen. Tujuan dari penelitian ini adalah untuk menganalisis bagaimana kualitas layanan Go-Jek mempengaruhi kepuasan pelanggan dalam membentuk loyalitas pelanggan pada perusahaan Go-Jek. Penelitian ini bersifat kuantitatif dan variabel yang diteliti dalam penelitian ini adalah desain website, kehandalan, kepercayaan, kepuasan pelanggan, untuk mendukung loyalitas konsumen. Penelitian ini dilakukan di Yogyakarta dengan pengumpulan data menggunakan kuesioner berbasis skala Likert, dan metode pengambilannya menggunakan purposive sampling dengan jumlah responden 300 orang. Data kemudian dianalisis menggunakan analisis Structural Equation Model (SEM) dengan bantuan software WarpPLS. Hasil penelitian menunjukkan bahwa pengaruh kualitas layanan elektronik terhadap loyalitas pelanggan pada perusahaan Go-Jek adalah positif dan signifikan.
\end{abstract}

Kata kunci: kualitas layanan elektronik, desain situs web, keandalan, kepuasan pelanggan, loyalitas pelanggan 


\section{INTRODUCTION}

Development of information technology and massive usages of mobile devices nowadays changes the shape and paradigm of business environment in Indonesia. Several innovations even able to affect general macro environment of the industry. Go-Jek, an online transportation company created by Nadiem Makarim and Michael Angelo Moran in 2011, is one example of service company that able to disrupt the industry, particularly in Indonesia's transportation and culinary industry. By using integrated mobile application, Go-Jek connects people who want to request transportation from one place to other places and drivers who able to deliver them to destination. Go-Jek also launched additional service called Go-Food, which make customers able to request food to be delivered by Go-Jek driver. Both of Go-Jek and Go-Food services are mainly used by Indonesia's society nowadays, creating the biggest market share of online transportation company in Indonesia. Go-Jek application has been installed by millions of Android and iOS users. Million transactions have been recorded every day, which can be considered as a high achievement for company that launched less than 10 years ago.

Go-Jek relies on the optimal usage of technology in order to provides best services for customers. Go-Jek maximized the potential use of internet to improve their services and become their competitive advantage. Transaction between customers and drivers can be conducted using Go-Jek application. The payment can be transferred using electronic money. Customers use Go-Food application to select restaurants and menus they want to order in their smartphone. Global Positioning System (GPS) technology also applied by Go-Jek, so customers able to track their orders via GPS option. All these conveniences can be provided thanks to optimal uses of information technology formulated by Go-Jek.
In quality management field, electronic service quality or e-service quality refers to measurement of technology usages, such as internet, to makes customers services more effective and efficient (Bressolles \& Durrieu, 2011). Quality in general means the abilities of products to meet customers' expectation (Heizer \& Render, 2011). E-service quality enhances the use of technology to improves services to be able to meet or even exceed customers' expectation. Li \& Suomi (2009) stated that e-service quality can be seen from two different perspectives. First perspective is company perspective, when company focus on building IT strategies and infrastructure in order to improve services provided to customers. These aspects can be identified by three important dimensions: platform or website design should be visually attractive and easy to use, reliability regarding consistency of web performances, and customers trust by providing fast and optimal services' information. The other perspective is customer perspective, which become the output of optimal company IT strategies. This perspective can be seen through the rate of customers' satisfaction (Savitri, 2016). In order to satisfy customers, company need to consider many alternative adjustments in order to meet customers' expectation. If company expectation is too high, it does not guarantee will satisfy customers and sometimes producing huge costs of implementation. While company expectation too low, it will disappoint customers for using their services. Therefore, understanding what customers really want is important for a company in order to applying IT strategies for their services.

When company IT strategies able to satisfy customers in the long run, it will generate customers' loyalty (Oliver, 1996). Johnson (1997) defined customer loyalty as a predisposition to purchase and use a product or service again, or tendency to buy or use a particular product and service again. Customer's satisfaction of a product 
and service will build trust for customers. Accumulated trust then makes customers loyal to one particular products. This effect also proofed by Setiawan \& Ukudi (2007) who found connectedness behavior that occurs between companies and consumers is largely determined by trust and commitment.

In this study, researcher try to examines relationship effects between company's perspective and customers' perspective of e-service quality in order to build customers' loyalty. Success story of Go-Jek had put researcher in interest to identify e-service quality of Go-Jek to build loyal customers. As e-commerce industry in Indonesia keep developing in rather dynamic environment, it needs more researches to determines optimal strategies in order to enter and persist in Indonesia's e-commerce market. This research would contribute to understand behaviors of Indonesia e-commerce customers' behavior, that may give positive direction for other e-commerce companies in Indonesia in order to determine future marketing strategy which focus on customers' loyalty.

\section{Website Design}

Several researches, such as researches by Van Riel \& Balmer (1997) and Walfinbarger \& Gilly (2003) stated the importance of website design in order to create customers' satisfaction. As website design related directly to user interface, the aspects of easiness, fascinating, and regular update of the web page are important factors to build customers' satisfaction. Lou et al. (2006) mentioned important dimensions of designing a website which consist of content, organization, structure of the site, and visual aspects such as appealing, fascinating, and pleasing to the eyes. While Liu et al. (2000) mentioned several important key design factors of a website that consist of information quality, service quality, playfulness, system design quality, and system use.
A number of studies related with ecommerce website have found many advantages of well-designed website. For instance, Liu et al. (2000) found that a welldesigned website would lead to better customers' recognition and attitude towards the site and its products. Other research also found positive relationship between website design and development of trust, due to effective communication (Eriksson et al., 2005).

$\mathrm{H}_{1}$ : Website design attributes have a
positive influence on customer
satisfaction

\section{Reliability}

One of five dimensions of service quality is reliability, the ability to perform the promised service dependably and accurately (Choi et al., 2005). Zeithaml et al. (2002) on his research stated that reliability has direct positive effect on customer satisfaction and service quality. Similar findings also mentioned by Lee et al. (2011) who identified the effects of reliability on online banking systems. Parasuraman et al. (2005) mentioned indicators represents the reliability of a website, which consist of the ability to fulfill orders correctly, deliver promptly, and keeping customer secure in order to get customers' satisfaction.

$\mathrm{H}_{2}$ : Reliability attributes have a positive influence on customer satisfaction

\section{Trust}

Trust can be formed when a person believes with another person or companies in a transaction. Uncertainly and risk are necessary conditions that create the value of the trust (Chervany, 2002). Trust also becomes viral factor in company's performance and profitability (Pavilia, 2009). In e-commerce business, when risks in transaction is higher, customers trust plays an important role to maintain customers' satisfaction and customers' loyalty. $\mathrm{Wu}$ (2013) mentioned three 
important dimensions of customers' trust related to company website, which are: the ability of company to meet customers' demands, integrity or reputation of the company, and predictability or customers' belief that company will fulfill their promises to customers.

$\mathrm{H}_{3}$ : Trust attributes have a positive influence on customer satisfaction

\section{Customer Satisfaction}

Customer satisfaction can be defined as a customer's evaluation of a product or service related to their needs and expectations (Oliver, 1996). Customers' satisfaction of a product or service will appear when the product able to fulfill or even exceed their expectation. According to Michaelidou \& Christodoulides (2011), there are positive antecedents between eloyalty, e-satisfaction, and perceived switching barriers, such as economic and emotional factors. Satisfied customers tend to buy more, loyal for longer times, and less sensitive to price changes. These findings indicate that when customers are satisfied, they tend to be loyal to a company because of they afraid to lose benefits they get from a company.

$\mathrm{H}_{4}$ : Customer satisfaction attributes have a positive influence on customer loyalty

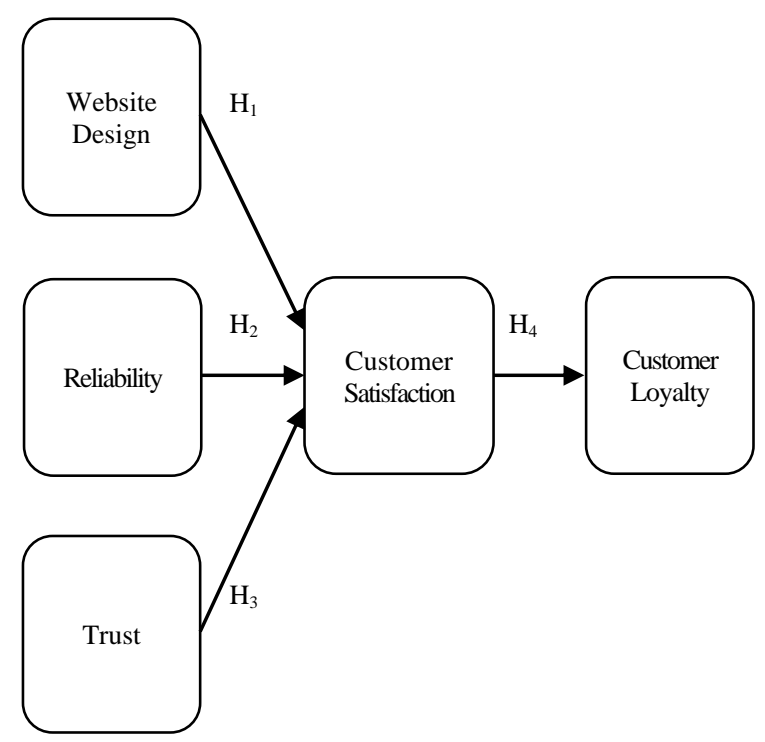

Figure 1. Research Model

\section{RESEARCH METHOD}

This research is conducted in quantitative approaches, in order to further explore of influencing factors of e-service quality to Go-Jek customers' satisfaction and loyalty. Factors measured in this research consist of website design of Go-Jek application, reliability of Go-Jek application, Go-Jek customers' trust, Go-Jek customers' satisfaction, and Go-Jek customers' loyalty. This research took data from 300 respondents of students who frequently use Go-Jek application in Yogyakarta area. Yogyakarta has been chosen as research location due to high density of Go-Jek service on those area, with students as their primary customers. Data have been taken for two months during April 2019 until June 2019.

Data for this research have been collected by questionnaire which distributed in to 300 university students in Yogyakarta area using Google Form and physical forms. Contents of questionnaire is divided into three parts; demographic questions, screening questions, and variable measurement questions. Each variable was measured using 1-6 Likert scale, which 1 represent "strongly disagree" statement from respondent to 6 score which represent "strongly agree" statement from respondent.

This research uses Structural Equation Modelling (SEM) technique in WarpPLS version 6 software for data analysis. Structural equation modelling consists of two main parts. First, confirmatory factor models measurement which linking observed variables with latent variables. Secondly, simultaneous equation regression that links latent variables (Ghozali \& Fuad, 2005). SEM is made from the development of model-based theory, development of causality relationship in flowchart, flowchart conversion into structural equation series and measurement of model specification, matrix input selection, and estimation technique on model, assessment of problem identification, model evaluation, and 
interpretation and modification of designated model (Hair et al., 2010).

\section{RESULTS AND DISCUSSION}

Total of respondents measured in this research are 300 respondents. In order to describe the response of each variable, the average value of variables have been calculated. Based on the calculation analysis, the average value of web design instrument is 4.85 , the average value of reliability instrument is 4.67 , the average value of trust instrument is 4.65 , the average value of customer satisfaction is 4.91 , and the average value of customer loyalty is 4.43 .

Demographic criteria of selected respondents based on gender are consist of $42,9 \%$ male and $57.1 \%$ female. $53.8 \%$ of respondents are in the age range between 18 to 21 years old, while other $46.2 \%$ of respondents are above 21 years old. $50.67 \%$ of respondents have monthly allowance for Rp1.000.001 to Rp2.000.000, while 24.67\% respondents have allowances below
Rp1.000.000 and 24.66\% respondents have allowances higher than Rp2.000.000. All of respondents are Yogyakarta undergraduate students who frequently use Go-Jek application, whether for transportation of other services such as food and packages delivery.

The objective of validity test is to determine the validity level of each statement to research variables. Data can be stated as valid if the standardize loading factor of each variable and average variance extracted (AVE) have meet the minimum value of 0.5 and minimum of $p$ value of 0.005 (Hair et al., 2010). While to determine reliability level, score of composite reliability and Cronbach's Alpha can be used. If both of composite reliability and Cronbach's Alpha score are above 0.7, instrument can be determined reliable (Hair et al., 2010). Both of validity test and reliability test of this research are conducted using WarpPLS software version 6. Output of validity test using WarpPLS is shown in the following Table 1 and Table 2.

Table 1. Convergent Validity and AVE

\begin{tabular}{|c|c|c|c|c|c|c|c|c|}
\hline Item & $\begin{array}{c}\text { Web } \\
\text { Design }\end{array}$ & Reliability & Trust & $\begin{array}{c}\text { Customer } \\
\text { Satisfactions }\end{array}$ & $\begin{array}{l}\text { Customer } \\
\text { Loyalty }\end{array}$ & P value & AVE & Result \\
\hline WD1 & 0.855 & & & & & $<0.001$ & & Valid \\
\hline WD2 & 0.883 & & & & & $<0.001$ & & Valid \\
\hline WD3 & 0.903 & & & & & $<0.001$ & 0.785 & Valid \\
\hline WD4 & 0.901 & & & & & $<0.001$ & & Valid \\
\hline R1 & & 0.836 & & & & $<0.001$ & & Valid \\
\hline $\mathrm{R} 2$ & & 0.879 & & & & $<0.001$ & 0.722 & Valid \\
\hline R3 & & 0.833 & & & & $<0.001$ & & Valid \\
\hline $\mathrm{T} 1$ & & & 0.894 & & & $<0.001$ & & Valid \\
\hline $\mathrm{T} 2$ & & & 0.911 & & & $<0.001$ & 0.81 & Valid \\
\hline $\mathrm{T} 3$ & & & 0.895 & & & $<0.001$ & & Valid \\
\hline CS1 & & & & 0.961 & & $<0.001$ & & Valid \\
\hline CS2 & & & & 0.961 & & $<0.001$ & 0.924 & Valid \\
\hline CL1 & & & & & 0.806 & $<0.001$ & & Valid \\
\hline CL2 & & & & & 0.799 & $<0.001$ & & Valid \\
\hline CL3 & & & & & 0.789 & $<0.001$ & 0.663 & Valid \\
\hline CL4 & & & & & 0.860 & $<0.001$ & & Valid \\
\hline
\end{tabular}

Table 2. Comparison of AVE Square Roots with Correlation

\begin{tabular}{llllll}
\hline & WD & \multicolumn{1}{c}{ R } & T & CS & CL \\
\hline WD & $\mathbf{0 . 8 8 6}$ & 0.703 & 0.753 & 0.78 & 0.64 \\
R & 0.703 & $\mathbf{0 . 8 5}$ & 0.738 & 0.723 & 0.596 \\
T & 0.753 & 0.738 & $\mathbf{0 . 9 0 0}$ & 0.804 & 0.612 \\
CS & 0.78 & 0.723 & 0.804 & $\mathbf{0 . 9 6 1}$ & 0.641 \\
CL & 0.64 & 0.596 & 0.612 & 0.641 & $\mathbf{0 . 8 1 4}$ \\
\hline
\end{tabular}

Based on validity analysis result shown in Table 1, it can be seen that all indicators loading factors value are more than 0.5 and $p$ value below 0.05. Analysis result also found that AVE score of each instrument is more than 0.5. On Table 2, AVE's square 
roots scores on every construct are differences or bigger rather than correlation scores on among other different constructs. Those results indicate that all indicators for this research are valid.

Table 3. Reliability Test Result

\begin{tabular}{lccc}
\hline Variables & $\begin{array}{c}\text { Composite } \\
\text { Reliability }\end{array}$ & $\begin{array}{l}\text { Cronbach's } \\
\text { Alpha }\end{array}$ & Result \\
\hline $\begin{array}{l}\text { Web } \\
\text { Design }\end{array}$ & 0.936 & 0.908 & Reliable \\
$\begin{array}{l}\text { Reliability } \\
\text { Trust }\end{array}$ & 0.886 & 0.807 & Reliable \\
$\begin{array}{l}\text { Customer } \\
\quad \text { Satisfaction }\end{array}$ & 0.928 & 0.883 & Reliable \\
$\begin{array}{c}\text { Costumer } \\
\text { Loyalty }\end{array}$ & 0.960 & 0.917 & Reliable \\
\hline
\end{tabular}

Table 3 shows that all variables in this research meet the minimum requirement of reliability. Both of composite reliability score and Cronbach's Alpha score are more than 0.7 , which indicate that all indicators are reliable.

Structural model test is conducted in order to identify the suitability of proposed model using WarpPLS software. Kock (2018) stated that Goodness of Fit of proposed research model can be acceptable if $p$ value of APC (average path coefficient), ARS (average R-Squared), and AARS (average adjusted R-Squared) are less than 0.005 . The result of structural model analysis on this research described on Table 4.

Based on structural model analysis described on Table 4, all of APC, ARS, and AARS value of $p$ are less than 0.005 (0.001). These results indicate that this proposed model is suitable for analysis. Structural model analysis also conducted multicollinearity analysis by providing score of AVIF (average block VIF) and AFVIF (average full collinearity AFVIF) of 3.447 and 3.011 with requirements of acceptable score if less than 5 and ideally less than 3.3. Thus, no multicollinearity happened on this proposed model. Suitability of the model is described on tenenhaus GoF score. Tenenhaus GoF score on this analysis stated that this model's suitability is small if $\mathrm{GoF} \geq 0.1$, medium if $\mathrm{GoF} \geq 0.25$, and large if $\mathrm{GoF} \geq 0.36$. Based on analysis output, the proposed model has tenenhaus GoF score of 0.670, which considered as largely suitable for further analysis.

Table 4. Model Fit and $P$ Value

\begin{tabular}{lr}
\hline \multicolumn{1}{c}{ Indicators } & \multicolumn{1}{c}{ Value } \\
\hline Average path coefficient (APC) & $\mathrm{P}<0.001$ \\
Average R-squared (ARS) & $\mathrm{P}<0.001$ \\
Average adjusted R-squared (AARS) & $\mathrm{P}<0.001$ \\
Average block VIF (AVIF) & 3.447 \\
Average full collinearity VIF (AFVIF) & 3.011 \\
Tenenhaus GoF (GoF) & 0.670 \\
\hline
\end{tabular}

Hypothesis are supported if $p$ value from hypothesis analysis meets minimum criteria, which less than 0.05 (Kock, 2018). The designated model has been tested using WarpPLS version 6 in order to determines $p$ value and and coefficient $\beta$ score for each hypothesis. The result of hypothesis testing can be described on Figure 2 .

Based on hypothesis testing using WarpPLS, all the hypotheses are supported. $\mathrm{H}_{1}$ has value of $\beta=0.32$ and $\mathrm{p}<0.01 . \mathrm{H}_{2}$ has value of $\beta=0.13$ and $p<0.01$. $\mathrm{H}_{3}$ has value of $\beta=0.45$ and $p<0.01$. Last, $\mathrm{H}_{4}$ has value of $\beta=0.65$ and $p<0.01$. Based on these results, all hypotheses have value of $\mathrm{p}<0.01$, which meet the requirement of supported hypothesis with $\mathrm{p}<0.05$.

The result of $\mathrm{H}_{1}$ indicates that design of a website would affects customers' satisfaction when they access the website or application of e-commerce company. Web design should be pleasing in the eye of customers, easy to use, and consist of useful features for customers. In e-commerce business, a website may just become secondary tools to assist customers for doing transaction. However, customers' initial perception of e-commerce company may come from its website. A good quality product may become unappealing if displayed through a bad-designed website. Website in e-commerce business become more than a tool, but also platforms for advertisement, virtual market, or communicating with seller, which giving huge impact on customers' satisfaction. This positive finding is congruent with 
several previous research findings such as researches by Van Riel \& Balmer (1997) and Walfinbarger \& Gilly (2003).

Result on $\mathrm{H}_{2}$ indicates that an ecommerce website not only need to be visually attractive, but also need to be accurate and dependable. One of ecommerce industry's character can be identified as a business platform where connection and information can be transferred in cheaper and easier ways rather than conventional business. Ecommerce companies need to build integrated IT systems where information flows can be transferred and updated in real time in order to make the whole system more reliable. Therefore, slow updates of information on the website will disappoint customers. As an up-to-date business platform, customers demand for no error whenever they access the web to do transactions. Maintaining the reliability of e-commerce websites also should triggering costumers reuse or repurchase in the future.

The positive influence of customers' trust on customers' satisfaction as stated on $\mathrm{H}_{3}$ indicates that e-commerce environments are full of uncertainly and insecurity. Many cases of frauds and errors on the system that give that harm customers in online business affected in customers' attitude to become more aware and sensitive when do online transaction. Supporting findings, such as in research by Pavilia (2009) mentioned that customers' trust is an important factor of online customers' satisfaction. Online customers' trust may be built and maintained from companies' good reputation, small error history record, transparency of transaction process, and also ability of company to do what they promised to customers.

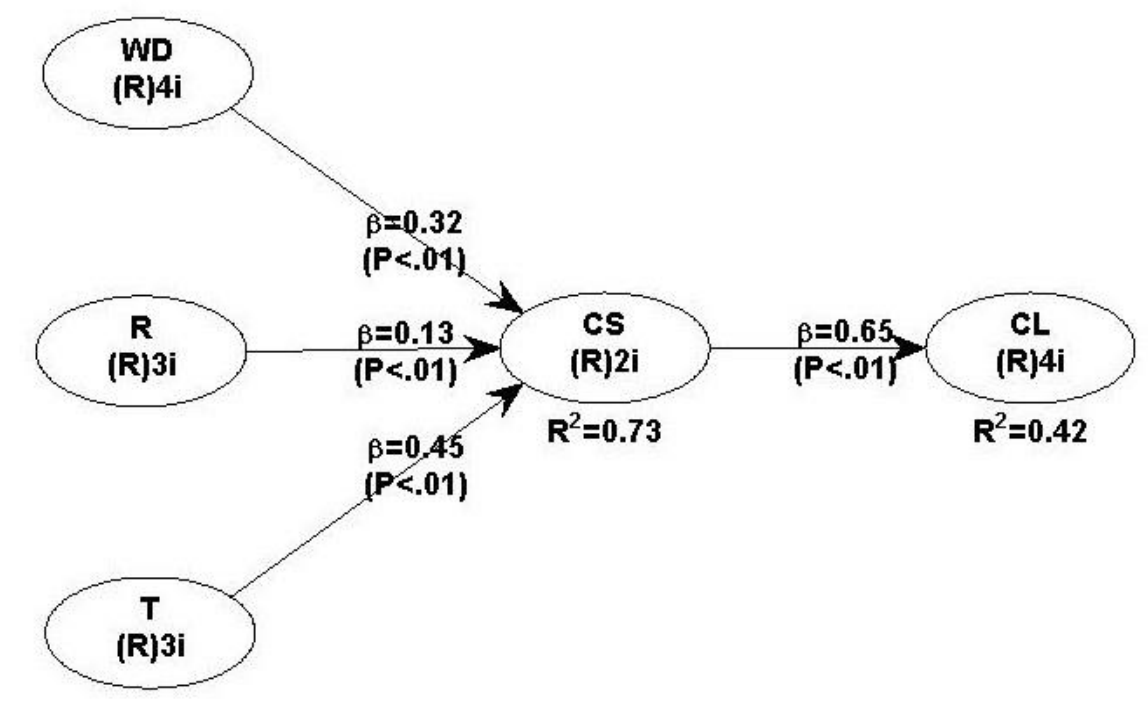

Figure 2. Hypothesis Testing Result

Result of $\mathrm{H}_{4}$ propose new finding regarding positive influence of customers' satisfaction on customers' loyalty specifically influenced from e-service quality aspect. Positive e-service quality in the long run will not only satisfy customers, but also would trigger customers to repurchase or reuse on particular ecommerce product. In this study, by focusing on giving best service quality,
Go-Jek able to maintain customer satisfaction that make Go-Jek customers' loyal to keep using Go-Jek application many times.

\section{CONCLUSION}

Result of this study indicates that variables of e-service quality of Go-Jek, which consist of web design, service reliability, and customers' trust positively influence 
Go-Jek customers' satisfaction. Go-Jek customers' satisfaction generated from positive e-service quality also able to influence customers' loyalty. This result also supported previous researches findings regarding e-service quality, which also found similar result of positive customers' satisfaction, whether it comes from web design, reliability, or customer' trust and interrelated influences among those aspects. While this research also identifies new finding regarding relationship between eservice quality aspects and customers' loyalty. This relationship has been mentioned in Fassnacht \& Koese (2006) research which suggested further empirical research regarding impacts of online service quality on satisfaction and loyalty. Michaelidou \& Christodoulides (2011) actually found positive antecedents between e-loyalty, e-satisfaction, and perceived switching barriers. This research confirms these theories by concluding positive influence of customers' satisfaction generated from e-service quality on customers' loyalty.

For further empirical studies, the researcher suggests to focus on another aspect not only the aspect that researcher analyze above as the object of this research and the researcher also can add the other factors to support customer satisfaction aspect and become customer loyalty aspect. The researcher also suggests can obtain the broader sample by taking the data sample not only to students under graduate in yogyakarta and giving the reasoning of the respondent to more accurate in analyze perception of the sample in explanation on this research, and besides that for the further research it will be better if researcher find more references to support this research in explanation.

\section{REFERENCES}

Bressolles, G., \& Durrieu, F. (2011). Service quality, customer value and satisfaction relationship revisited for online wine websites. 6th AWBR
International Conference. France: Bordeaux Management School.

Chervany, D. H. (2002). What trust means in e-ecommerce customeer relationships? An interdisciplinary conceptual typology. Internet Journal Electronic Commerce, 6(2), 35-59.

Choi, K., Lee, H., Kim, C., \& Lee, S. (2005). The service quality dimensions and patient satisfaction relationships in South Korea: comparisons across gender, age and types of service. Journal of Services Marketing, 140-149.

Eriksson, K., Kerem, K., \& Nilsson, D. (2005). Customer acceptance of internet banking in Estonia. International Journal of Bank Marketing, 23(2), 200-16.

Fassnacht, M., \& Koese, I. (2006). Quality of electronic services: conceptualizing and testing a hierarchical model. Journal of service research, 9(1), 19-37.

Ghozali, I., \& Fuad. (2005). Structural Equation Modeling: Teori, Konsep, dan Aplikasi. Semarang: Badan Penerbit Universitas Diponegoro.

Hair, J. F., Black, W. C., Babin, B. J., \& Anderson, R. E. (2010). Multivariate Data Analysis 7th ed. New Jersey: Prentice Hall.

Heizer, J., \& Render, B. (2011). Operations management 10th edition. Upper Saddle River: Pearson.

Johnson, D. M. (1997). Customer orientation \& market action. Englewood Cliffs, New Jersey: Prentice Hall International Inc.

Kock, N. (2018). Minimum sample size estimation in PLS-SEM: an application in tourism and hospitality research. In Applying partial least squares in tourism and hospitality research. Emerald Publishing Limited.

Lee, J., Kim, H., Ko, Y., \& Sagas, M. (2011). The influence of service quality on satisfaction and intention: 
A gender segmentation strategy. Sport Management Review, 54-63.

Li, H., \& Suomi, R. (2009). A proposed scale for measuring e-service quality. International Journal of $u$-and $e$ Service, Science and Technology, 2(1), 1-10.

Liu, C., Atnett, K. P., \& Litecky, C. (2000). Design quality of websites for electronic commerce: fortune 1000 webmasters' evaluations. Electronic Marketers, 10(2), 120-129.

Lou, J. T., McGoldrick, P., Beatty, S., \& Keeling, K. A. (2006). On-screen characters: their design and influence on consumer trust. Journal of Services Marketing, 2(2), 112-24.

Michaelidou, N., \& Christodoulides, G. (2011). Antecedents of attitude and intention towards counterfeit symbolic and experiential products. Journal of Marketing Management, 976-991.

Oliver, R. L. (1996). Varieties of Value in the Consumption Satisfaction Response. In K. P. Corfman \& J. G. Lynch Jr. (Eds.), NA - Advances in Consumer Research, (23rd ed., pp. 143-147). Provo, UT: Association for Consumer Research.

Parasuraman, A., Zeithaml, V., \& Malhotra, A. (2005). ES-QUAL: a multipleitem scale for assessing electronic service quality. Journal of service research, 213-233.

Pavilia, P. (2009). The role of trust in ecommerce relational exchange.
Information and Management, 46(2), 213-220.

Savitri, E. (2016). The Effect of Taxpayer Awareness, Tax Socialization, Tax Penalties, Compliance Cost at Taxpayer Compliance with Service Quality as Mediating Variable. Procedia-Social and Behavioral Sciences, 219, 682-687.

Setiawan, M. B., \& Ukudi. (2007). Pengaruh Kualitas Layanan, Kepercayaan \& Komitmen terhadap Loyalitas Nasabah. Jurnal Bisnis \& Ekonomi (JBE), 14(2).

Van Riel, C., \& Balmer, J. (1997). Corporate identity: the concept, its measurement and management. European journal of marketing, 340355.

Walfinbarger, M., \& Gilly, M. G. (2003). eTailQ: dimensionalizing, measuring and predicting etail quality. Journal of retailing, 79(3), 183-98.

$\mathrm{Wu}$, I. L. (2013). The antecedents of customer satisfaction and its link to complaint intentions in online shopping: An integration of justice, technology, and trust. International Journal of Information Management, 33(1), 166-176.

Zeithaml, V. A., Parasuraman, A., \& Malhotra, A. (2002). Service quality delivery through web sites: a critical review of extant knowledge. Journal of the academy of marketing science, 30(4), 362-375. 
